\title{
KONTROL DIRI DAN DUKUNGAN SOSIAL ORANG TUA TERHADAP KEDISIPLINAN PADA SISWA SMK DENGAN MOTIVASI BELAJAR SEBAGAI VARIABEL INTERVENING
}

\author{
Umi Farida Febriani ${ }^{1}$, Rini Sugiarti ${ }^{2}$ \\ 1,2Magister Psikologi Universitas Semarang \\ Email: ${ }^{1}$ umifarida2402@gmail.com, ${ }^{2}$ rinisugiartipsikologi@usm.ac.id
}

Article History:

Received

23 April 2021

Review

19 Mei 2021

Revised

31 Mei 2021

Accepted

2 Juni 2021

Published

23 Juni 2021

Reviewer A:

Muhammad Abd Hadi Bunyamin
Abstract.This study aims to 1) determine the effect of self-control on discipline behaviour in vocational students, 2) determine the effect of parental social support on discipline behaviour in vocational high school students, 3) determine the effect of learning motivation on discipline behaviour in vocational high school students, 4) determine the effect of self-control on discipline through motivation learning on vocational high school students, 5) understanding the effect of parental social support on discipline through learning motivation in vocational high school students. The subjects in this study were 88 students. This study uses a population study technique. Data analysis used path analysis using the SmartPLS 3.0 program. The results showed 1) there was a positive effect of self-control on discipline in vocational high school students with $p=0.021$ where $p<0.05,2)$ there was a positive effect of parental social support on discipline in vocational students with $p=0.037$ where $p<0.05,3)$ there is a positive influence of learning motivation on the discipline of vocational students with $p=$ 0.001 where $p<0.005,4)$ there is a positive influence of self-control on discipline through learning motivation in vocational students with $p=$ 0.014 where $p<0.05,5)$ there is positive influence of parental social support on discipline in vocational students with $p=0.003$ where $p$ $<0.05$.

Keywords : discipline, self-control, parental social support, learning motivation, students

Abstrak. Penelitian ini bertujuan untuk 1) mengetahui pengaruh kontrol diri terhadap kedisiplinan pada siswa SMK, 2) mengetahui pengaruh dukungan sosial orang tua terhadap kedisiplinan pada siswa SMK, 3) mengetahui pengaruh motivasi belajar terhadap kedisiplinan pada siswa SMK, 4) mengetahui pengaruh kontrol diri terhadap kedisiplinan melalui motivasi belajar pada siswa SMK, 5) mengetahui pengaruh dukungan sosial orang tua terhadap kedisiplinan melalui motivasi belajar pada siswa SMK. Subjek dalam penelitian ini berjumlah 88 siswa. Penelitian ini menggunakan teknik studi populasi. Analisis data menggunakan analisis jalur dengan menggunakan program SmartPLS 3.0. Hasil penelitian menunjukkan 1) ada pengaruh positif kontrol diri terhadap kedisiplinan pada siswa SMK dengan $\mathrm{p}=0,021$ dimana $\mathrm{p}<0,05,2$ ) ada pengaruh posistif dukungan sosial orang tua terhadap kedisiplinan pada siswa SMK dengan $\mathrm{p}=0,037$ dimana $\mathrm{p}<0,05,3$ ) ada pengaruh positif motivasi belajar terhadap kedisiplinan siswa SMK dengan $p=0,001$ dimana $p<0,005,4)$ ada pengaruh posistif kontrol diri terhadap kedisiplinan melalui motivasi belajar pada siswa SMK dengan $p=0,014$ dimana 
$\mathrm{p}<0,05,5)$ ada pengaruh positif dukungan sosial orang tua terhadap kedisiplinan pada siswa SMK dengan $\mathrm{p}=0,003$ dimana $\mathrm{p}<0,05$.

Kata kunci : kedisiplinan, kontrol diri, dukungaan sosial orang tua, motivasi belajar, siswa

\section{Pendahuluan}

Siswa sebagai peserta didik dalam lingkungan sekolah atau masyarakat diharapkan bisa bertingkah laku, bersikap baik dan sopan kepada siapa saja serta bisa menghormati dan menghargai orang lain. Siswa sebagai peserta didik dari proses pendidikan memiliki suatu kewajiban yang harus dilaksanakan, yaitu siswa dituntut untuk bertingkah laku sesuai dengan norma-norma yang ada. Siswa juga dituntut untuk menaati taat tata tertib sekolah menuju keberhasilan proses belajar mengajar, membentuk karakterisitik siswa agar disiplin dan bertanggung jawab dan dapat menampilkan perilaku yang diharapkan sesuai dengan lingkungan sekitar.

Disiplin terhadap tata tertib sangat penting untuk diterapkan, karena jika dalam suatu sekolah tidak memiliki tata tertib maka proses belajar mengajar tidak akan berjalan dengan lancar sesuai dengan rencana. Dengan tingkat kedisiplinan yang tinggi, diharapkan dapat memberikan dukungan bagi terciptanya perilaku siswa yang tidak menyimpang, serta memiliki kebiasaan yang baik, positif dan bermanfaat bagi diri dan lingkungannya.

Menurut Hasibuan (2013: 193) kedisiplinan adalah kesadaran dan kesediaan seseorang menaati semua peraturan perusahaan dan norma-norma sosial yang berlaku. Pentingnya disiplin diajarkan sejak dini diharapkan mampu melahirkan kepribadian dan jati diri, serta sifat-sifat positif, sehingga dengan disiplin akan membentuk etos kerja yang tinggi serta tanggung jawab dan komitmen yang kuat, yang pada akhirnya akan mengantarkan remaja menjadi sember daya manusia yang berkualitas. Dalam kehidupan sehari-hari dikenal disiplin diri, disiplin belajar, dan disiplin kerja. Seseorang dikatakan memiliki disiplin diri yang kuat jika dapat mengendalikan diri sendiri. Menurut Rimm (dalam Elly, 2016: 48) tujuan disiplin adalah mengarahkan anak untuk mereka belajar mengenal hal-hal baik yang merupakan persiapan bagi masa dewasa, saat mereka bergantung kepada disiplin diri.

Siswa di sekolah diharapkan mematuhi segala peraturan yang telah ditetapkan. Semua peraturan telah dirangkum dan dijabarkan dalam tata tertib yang berbeda satu dengan lainnya yang tentunya sudah disesuaikan dengan karakteristik sekolah. Dengan adanya tata tertib, maka setiap tindakan dan perilaku siswa akan dikontrol, sehingga kedisiplinan siswa disekolah akan tercipta. Haryono (2016: 262) menyatakan bahwa didalam proses belajar mengajar, disiplin terhadap tata tertib sangat penting untuk 
diterapkan karena jika dalam suatu sekolah tidak memiliki tata tertib maka proses belajar mengajar tidak akan berjalan dengan lancar sesuai dengan rencana. Menciptakan kedisiplinan siswa bertujuan untuk mendidik siswa untuk sanggup memerintahkan diri sendiri.

Disiplin bertujuan untuk menanamkan pola perilaku tertentu, kebiasaaan tertentu, membentuk manusai dengan ciri tertentu, terutama untuk meningkatkan kualitas mental dan moral. Lestari dan Nursalim (2019: 19) dalam penelitiannya menyatakan bahwa siswa SMA Negeri 11 Surabaya kurang mampu dalam mengendalikan diri terutama dalam hal kedisiplinan terhadap peraturan sekolah.

Pelanggaran yang sering dilakukan antara lain datang terlambat ke sekolah, bermain handphone saat pelajaran berlangsung, telat mengumplkan tugas bahkan ada yang tidak mengumpulkan tugas, keluar saat jam pelajaran berlangsung, berbicara kotor dan kotor, tidak memakiai atribut sekolah, dari fenomena tersebut menunjukkan bahwa masih rendahnya kedisiplinan di sekolah tersebut.

Perilaku indisipliner pada beberapa fenomena di sekolah banyak dilakukan oleh siswa dalam fase remaja. Hal ini kemudian dijelaskan dalam teori Erickson (Santrock, 2012: 402) bahwa remaja termasuk dalam tahap perkembangan identitas dan kebingungan indentitas (identity versus identity confusion). Pada tahap ini remaja dihadapkan dengan banyak peran baru dan status orang dewasa. Jika remaja menjalankan peran secara positif maka indentitas yang dicapai pun akan positif juga.

Melakukan kedisiplinan memang sangatlah sulit bagi seseorang tapi ketika membiasakan diri untuk terus disiplin sangatlah berguna bagi kehidupan. Dalam melalukan atau menerapkan kedisiplinan dalam diri seseorang perlu banyak bagian dalam penerapannya. Banyak faktor yang mempengaruhi kedisiplinan dalam diri seorang, yaitu faktor eksternal adalah adanya dukungan sosial dari orang disekitar seperti guru, teman sebaya, dan juga orang tua, selain itu juga didukung faktor internal berupa kontrol diri untuk mengendalikan perilaku negatif serta motivasi belajar siswa dalam menunjang prestasi belajar.

Berikut ini adalah data pelanggaran disiplin siswa SMK "X" Semarang Periode 2018-2019, diperoleh peneliti melalui hasil rekapan dari surat pernyataan pelanggaran siswa yang diisi setiap siswa melakukan pelanggar 
Philanthropy Journal of Psychology

Vol 5 Nomor 1 (2021), 92-108

ISSN 2580-6076 (Print), ISSN 2580-8532 (Online)

Tabel 1. Data Pelanggaran Siswa SMK "X" Semarang

\begin{tabular}{|c|c|c|}
\hline No. & Jenis Pelanggaran & Jumlah Pelanggaran \\
\hline 1 & Terlambat masuk sekolah & 15 \\
\hline 2 & Tidak mengerjakan tugas & 11 \\
\hline 3 & Sering ijin saat KBM dengan alasan sakit & 4 \\
\hline 4 & Tertangkap sedang merokok & 8 \\
\hline 5 & Tidak mengikui pelajaran & 7 \\
\hline 6 & $\begin{array}{l}\text { Mendengarkan musik dengan headset saat KBM } \\
\text { berlangsung }\end{array}$ & 6 \\
\hline 7 & Bermain HP saat KBM berlangsung & 5 \\
\hline 8 & Menyebarkan dan membuat gambar IT yang tidak baik & 4 \\
\hline 9 & Merokok elektrik & 6 \\
\hline 10 & $\begin{array}{l}\text { Terjaring razia (tertengkap basah sedang nongkrong di } \\
\text { warung kopi dan maen PS) }\end{array}$ & 5 \\
\hline 11 & $\begin{array}{l}\text { Tertangkap basah sedang mengedarkan obat- } \\
\text { obatan/narkoba }\end{array}$ & 2 \\
\hline 12 & Merokok di toilet saat KBM berlangsung & 4 \\
\hline 13 & Rambut tidak sesuai perturan sekolah & 18 \\
\hline 14 & Menyebarkan video porno & 3 \\
\hline \multicolumn{2}{|r|}{ Jumlah } & 92 \\
\hline
\end{tabular}

Sumber: Data Catatan Pelanggaran Sekolah SMK "X" Semarang (2020)

Berdasarkan dari data di atas, terkait dengan pelanggaran yang dilakukan oleh siswa SMK "X" Semarang, dapat disimpulkan bahwa banyak siswa yang masih melakukan pelanggaran kedisiplinan yang sudah di tetapkan oleh sekolah meskipun peraturan yang ada di sekolahan sudah cukup ketat.

Penelitian Indriani (2013: 38) menyatakan bahwa terdapat 20\% pelanggaran siswa disekolah, antara lain siswa terlambat datang ke sekolah, membolos, memakai atribut seragam tidak lengkap, tidak membawa buku pelajaran, dan kurang memperhatikan pelajaran. Pelanggaran tersebut menunjukkan bahwa siswa tidak memiliki perilaku disiplin. Strategi untuk menangani permasalahan dengan memberi nasehat dan teguran kepada siswa. Namun masih ada siswa yang mlakukan pelanggaran. Bentuk pelanggaran tersebut dikarenakan kurangnya kontrol diri yang dimiliki oleh siswa.

Beberapa anggapan keliru dalam pemberlakuan kedisiplinan disekolah oleh siswa. Banyak siswa yang tidak memahami pentingnya penegakan aturan yang diberlakukan terhadap mereka, sehingga siswa meras terbebani dan terkadang sulit untuk mengikuti aturan yang berlaku. Jika siswa memahami pentingnya kedisiplinan, maka siswa tidak akan merasa berat untuk mengukuti aturan tersebut. Rendahnya kesadaran dalam disiplin, selebihnya disiplin dalam tata tertib hanya didasarkan sebagai paksaan. Akibatnya, siswa belum banyak menyadari bahwa perilaku disiplin terhadap tata tertib 
sebenarnya merupakan tangung jawab pribadi dan akan memberikan manfaat pada siswa. Perilaku disiplin akan lebih mudah tumbuh dan berkembang bila muncul dari kesadaran dalam diri seseorang.

Perilaku kedisiplinan siswa dapat diprediksi melalui kontrol diri. Hal tersebut sesuai dengan penelitian yang dilakukan oleh Ningsih (2018) yang menunjukan bahwa Kontribusi kontrol diri terhadap tingkat kedisiplinan sebesar 46,5\%. Kontrol diri memungkinkan remaja untuk berpikir atau berperilaku yang lebih terarah, dapat menyalurkan dorongan-dorongan perasaan dalam dirinya secara benar dan tidak menyimpang dari norma-norma dan aturan-aturan yang berlaku di lingkungan sekitarnya (Hurlock, 2013). Kemampuan mengontrol diri dapat membantu individu untuk berperilaku lebih terarah dan dapat menyalurkan dorongan dalam dirinya secara benar, sehinggap dapat mencegah perbuatan melanggar norma atau peraturan yang berlaku (Nurani, 2018:182).

Dalam penerapannya kedisiplinan salah satunya dipengaruhi oleh faktor kontrol diri. Ningsih (2015: 4) menyatakan bahwa kontrol diri merupakan kemampuan kontrol seseorang yang akan tampak pada perhitungan yang matang sebelum membuat keputusan, menguasai dorongan emosi secara tepat, dan pertimbangan kognitif yang baik. Selain itu, juga kemampuan untuk mengontrol dan mengelola faktor-faktor perilaku sesuai dengan situasi dan kondisi untuk menampilkan diri dalam melakukan sosialisasi kemampuan untuk mengendalikan perilaku, kecenderungan menarik perhatian, keinginan mengubah perilaku agar sesuai untuk orang lain, menyenangkan orang lain, selalu nyaman dengan orang lain, dan menutupi perasaannya. Siswa yang memiliki kontrol diri yang baik ditandai dengan dengan adanya sikap patuh terhadap aturan, norma dan kondisi sosial.

Di dalam sekolah siswa dapat belajar meningkatkan kedisiplinan melalui pentaatan atau mengikuti peraturan- peraturan yang berlaku di sekolah, dalam hal ini guru sebagai pengamat dan juga pendidik mempunyai peran penting dalam peningkatan kedisiplinan seorang siswa, dukungan yang diberikan guru juga mampu membuat peserta didik menjadi lebih baik dalam kedisiplinan, selain guru di dalam sekolah teman-teman sebaya juga menjadi faktor atau pendukung dalam peningkatan kedisiplinan. Selain didalam sekolah peserta didik juga diharapkan diajarkan kedisiplinan didalam lingkungan keluarga dan masyarakat, ini membuat orang tua diharapkan mampu membantu meningkatkan kedisiplinan. Membangun kepribadian yang baik diperlukan lingkungan keluarga yang mimiliki sikap disiplin yang baik sehingga siswa setaip harinya akan terlatih 
untuk bertindak disiplin dan penuh tanggung jawab. Hal tersebut memicu bahwa kedisiplinan siswa juga didukung dengan adanya dukungan sosial orang tua

Selain kontrol diri faktor yang berpengaruh adalah dukungan sosial dan dukungan sosial dalam hal ini adalah dukungan sosial orang tua. Menurut Stern (dalam Wicaksono,2014: 132) faktor yang memengaruhi kedisiplinan salah satunya adalah faktor dari luar yaitu lingkungan, dimana faktor lingkungan terutama dukungan sosial dapat memengaruhi seseorang untuk bersikap disiplin. Selain itu faktor nilai dan norma dalam keluarga, dimana norma atau nilai tertentu diperoleh dan pola asuh orang tua dalam membimbing anaknya, macam-macam aturan, dan norma wajib dan harus dipatuhi demi kebaikan dan masa depan anaknya.

Bentuk dukungan yang diberikan orang tua kepada anaknya antara lain adalah dukungan fisik dan psikologis. Dukungan fisik wujudnya adalah pemberian barang yang menunjang proses belajar siswa, sedangkan dukungan psikologis adalah dukungan yang diwujudkan dengan memberikan perhatian, kasih sayang dan nasihat, contohnya dengan bertanya mengenai pelajaran yang di ajarkan oleh guru dan membantu dalam belajar dengan cara mengontrol siswa tersebut (Sani, 2019: 319).

Orang tua memiliki kewajiban untuk mendidik, mengasuh dan membimbing anaknya untuk menuju tahapan tertentu yang mengantarkan anak-anaknya siap dalam keidupan masyarakat. Orang tua juga dapat membantu mengurangi ketegangan akibat masalah yang dihadapi dengan memberikan bantuan emosional dan membantu menyelesaikan masalah bahkan masyarakat sangat berpengaruh besar dalam pendidikan disiplin anak dimana anak tinggal.

Guru dan orang tua bekerjasama untuk mengatasi perilaku ketidakdisiplinan dengan memberikan sanksi baik lisan, tertulis maupun tindakan lainnya. Mayasari (2016: 1.688) menyatakan bahwa dukungan sosial yang diberikan orang tua akan memberikan dampak positif bagi siswa. Dukungan sosial itu sendiri secara umum mengacu pada bantuan yang diberikan kepada siswa oleh orang-orang yang berarti baginya seperti keluarga dan teman-teman. Dukungan sosial yang diberikan orang tua berfungsi memberikan perasaan diterima, diperhatikan disayangi, dihargai dan dicintai. Dengan adanya hal tersebut mereka akan merasa bahagia dan tenang karena merasa ada orang yang membantunya bila mendapatkan kesulitan dalam bersikap disiplin di sekolah. Dukungan sosial orang tua juga dapat berfungsi sebagai reward dan dapat mengarahkan serta mendorong siswa untuk disiplin. 
Motivasi belajar juga mempengaruhi kedisiplinan siswa. Disiplin menerapkan pada kebebasan individu untuk tidak bergantung kepada orang lain dalam memilih, membuat keputusan, tujuan, melakukan perubahan perilaku, pikiran maupun emosi sesuai dengan prinsip yang diyakini dari aturan yang dianut. Disiplin adalah perilaku sosial yang bertanggung jawab dan fungsi kemandirian yang optimal dalam suatu relasi sosial yang berkembang atas dasar kemampuan mengelola, mengendalikan, memotivasi dan idenpendensi diri (Wicaksono, 2014: 134).

Hal ini sesuai dengan penelitian Al Baqi (2017: 85) menyatakan bahwa motivasi merupakan hal penting yang mempengaruhi perilaku disiplin santri di pondok pesantren. Pertama adalah motivasi eksternal yang mempengaruhi siswa untuk perilaku tidak disiplin, faktor tersebut meliputi pengaruh perilaku buruk teman, ada kesempatan untuk melakukan perilaku tidak disiplin dan masalah pribadi yang dibawa dari keluarga mereka. Kedua, motivasi internal yang mempengaruhi untuk melakukan perilaku tidak disiplin, diantaranya karena santri kurang mampu beradaptasi dengan lingkungan asrama, tidak dapat menerapkan aturan (bisa secara fisik atau mental), tidak memiliki tujuan atau citacita hidup yang jelas, dan memendam kemarahan atau membenci kepada penegak disiplin (santri senior atau guru). Ketiga, adalah motivasi eksternal yang mempengaruhi perilaku disiplin, diantaranya adalah dukungan dari orang tua, takut akan hukuman, pengaruh teman-teman yang taat aturan, dan ingin dianggap baik oleh orang lain. Keempat, adalah motivasi internal perilaku disiplin, seperti pemahaman mereka dan fungsi menjadi disiplin, mampu beradaptasi dengan sistem asrama, memiliki kontrol diri yang baik dan memiliki motivasi tinggi ketika mendatangi pesantren.

Kedisiplinan merupakan salah satu kunci keberhasilan peserta didik dalam belajar. Mendisiplinkan siswa tidak mudah karena membutuhkan kesadaran diri dari siswa dan perlu adanya pemberian dorongan dari orang tedekat. Menurut Sugiarto, Tri dan Padmi (2019: 233) siswa yang memiliki kedisiplinan yang baik akan berusaha mengatur dan menggunakan strategi dan cara belajar yang tepat dan mempunyai kesadaran atas tanggung jawab pribadi. Kedisiplinan dan motivasi belajar merupukan dasar untuk mencapai prestasi yang baik.

\section{Metode penelitian}

Metode penelitian yang digunakan adalah deskriptif dengan pendekatan kuatitatif. PeneliTan ini mengambil subjek siswa SMK sebanyak 88 siswa. Adapun karakteristik populasi dalam penelitian ini adalah siswa kelas XI SMK "X" Semarang yang belum pernah mengikuti penelitian. Teknik pengambilan sampel dalam penelitian ini adalah studi 
populasi atau sampel jenuh, peneliti dalam menggunakan teknik sampel ini karena jumlah sampel sama dengan jumlah populasi. Hal ini sering dilakukan bila jumlah populasi relatif kecil penelitian yang ingin membuat generalisasi dengan kesalahan yang sangat kecil (Sugiyono, 2016: 85). Data penelitian dikumpulkan dengan menggunakan empat skala yaitu skala kedisiplinan, sakal kontrol diri, skala dukungan sosial dan skala motivasi belajar. Analisis data menggunakan analisis jalur dengan menggunakan program SmartPLS 3.0.

\section{Hasil penelitian}

Tahap setelah pengumpulan yaitu pemberian skor terhadap masing-masing item untuk kemudian di uji validitas dan reliabilitas dan setelah itu dilakukan proses analisis jalur menggunakan program SmartPLS 3.0 untuk membuktikan hasil hipotesis penelitian.

\section{Uji validitas dan reliabilitas hasil penelitian}

\section{a. Uji Validitas}

Pengujian validitas item dengan menggunakan bantuan program SmartPLS 3.0. Langkah pertama yang dilakukan dalam pengujian SEM PLS uji validitas adalah mengukur model dengan kriteria nilai outer loading pada masing-masing variabel yang diteliti. Dengan patokan nilai loading ideal yang diharapkan adalah $>0.7$. Dari hasil pengukuran ada beberapa butir soal yang gugur pada masing-masing variabel. Butir soal yang memiliki nilai loading $>0.7$ dinyatakan valid dan dipakai untuk pengukuran selanjutnya. Sedangkan butir soal yang memiliki nilai loading $<0.5$ dikeluarkan dari model. Setelah itu model disusun kembali dan diukur ulang dalam model modifikasi. Convergent validity diukur dengan menggunakan parameter outer loading dan AVE (Average Variance Extraced).

\section{Skala Kedisiplinan}

Penyusunan skala kedisiplinan yang semula berjumlah 32 item, terdapat 9 item yang gugur sehingga tersisa 24 item yang valid. Koefisien validitas item berkisar antara 0.736 sampai 0.889

\section{Skala Kontrol Diri}

Penyusunan skala kontrol diri yang semula berjumlah 24 item, terdapat 8 item yang gugur sehingga tersisa 16 item yang valid. Koefisien validitas item berkisar antara 0.724 sampai 0.861 .

\section{Skala Dukungan Sosial Orang tua}

Penyusunan skala dukungan sosial orang tua yang semula berjumlah 32 item, terdapat 7 item yang gugur sehingga tersisa 25 item yang valid. Koefisien validitas item berkisar antara 0.729 sampai 0.845 . 
Philanthropy Journal of Psychology

Vol 5 Nomor 1 (2021), 92-108

ISSN 2580-6076 (Print), ISSN 2580-8532 (Online)

\section{Skala Motivasi Belajar}

Penyusunan skala motivasi belajar yang semula berjumlah 20 item, terdapat 6 item yang gugur sehingga tersisa 14 item yang valid. Koefisien validitas item berkisar antara 0.829 sampai 0.890

\section{b. Uji Reliabilitas}

Uji reliabilitas dilakukan untuk membuktikan akurasi, konsistensi, dan ketepatan instrumen dalam mengukur suatu konstruk. Dalam PLS - SEM dengan menggunakan SmartPLS, untuk mengukur reliabilitas suatu konstruk dapat dilakukan dengan dua cara, yaitu dengan Cronbach's Alpha dan Composite reliability.

Tabel 2. Uji Reliabilitas

\begin{tabular}{l|c|c|c|c}
\hline \multicolumn{1}{c|}{ Variabel } & $\begin{array}{c}\text { Cronbach's } \\
\text { Alpha }\end{array}$ & $\begin{array}{c}\text { rho } \\
\text { A }\end{array}$ & $\begin{array}{c}\text { Reliabilitas } \\
\text { Komposit }\end{array}$ & $\begin{array}{c}\text { Rata-rata Varians } \\
\text { Diekstrak (AVE) }\end{array}$ \\
\hline $\begin{array}{l}\text { Dukungan Sosial } \\
\text { Orang Tua }\end{array}$ & 0.975 & $\begin{array}{c}0.97 \\
7\end{array}$ & 0.977 & 0.629 \\
\hline Kedisiplinan & 0.982 & $\begin{array}{c}0.98 \\
2\end{array}$ & 0.983 & 0.716 \\
\hline Kontrol Diri & 0.963 & $\begin{array}{c}0.96 \\
4\end{array}$ & 0.967 & 0.645 \\
\hline Motivasi Belajar & 0.973 & $\begin{array}{c}0.97 \\
3\end{array}$ & 0.975 & 0.738 \\
\hline
\end{tabular}

Sumber: Data Primer diolah, 2021

Dari tabel diatas dapat dilihat bahwa nilai semua variabel dalam pengujian reliabilitas baik menggunakan Cronbach's Alpha ataupun Composite reliability nilainya > 0.70, dan pengujian validitas dengan menggunakan AVE (Average Variance Extracted) nilainya $>0.50$. Oleh karena itu, dapat disimpulkan bahwa variabel - variabel yang diujikan valid dan juga reliabel, sehingga dapat dilanjutkan untuk menguji model struktural.

\section{c. Analisis Model Struktural (Inner Model)}

Evaluasi model struktural atau inner model bertujuan untuk memprediksi hubungan antar variabel laten

\section{R-Square $\left(R^{2}\right)$}

Tabel 3. Nilai $\mathbf{R}^{2}$ Variabel Endogen

\begin{tabular}{l|r|r}
\multicolumn{1}{c|}{ Variabel } & R Square & \multicolumn{2}{c}{ Adjusted R Square } \\
\hline Kedisiplinan & 0.726 & 0.717 \\
\hline Motivasi & 0.452 & 0.439 \\
\hline
\end{tabular}

Sumber: Data Primer diolah, 2021

Berdasarkan tabel dapat disimpulkan bahwa pengaruh kontrol diri dan dukungan sosial terhadap motivasi memberikan nilai sebesar 0.452 , yang dapat diinterprestasikan 
bahwa variabilitas motivasi yang dapat dijelaskan oleh variabilitas kontrol diri dan dukungan sosial adalah sebesar $45.2 \%$ sedangkan sisanya dijelaskan oleh variabel lain diluar penelitian ini. Begitu juga dengan pengaruh kontrol diri, dukungan sosial dan motivasi terhadap kedisiplinan memberikan nilai sebesar 0.726, yang dapat di interprestasikan bahwa variabilitas kedisiplinan yang dapat dijelaskan oleh variabilitas konstruk kontrol diri, dukungan sosial dan motivasi adalah sebesar $72.6 \%$, sedangkan sisanya dijelaskan oleh variabel - variabel diluar penelitian ini.

\section{Uji Hipotesis}

Gambar. Pengujian Model Struktural

Berikut hipotesis - hipotesis yang diajukan dalam penelitian ini:

Tabel 4. Path Coefficient

\begin{tabular}{l|c|c|c|c|c}
\hline \multicolumn{1}{c|}{ Jalur } & $\begin{array}{c}\text { Sampel } \\
\text { Asli } \\
(\mathrm{O})\end{array}$ & $\begin{array}{c}\text { Rata-rata } \\
\text { Sampel } \\
(\mathrm{M})\end{array}$ & $\begin{array}{c}\text { Standar } \\
\text { Deviasi } \\
\text { (STDEV) }\end{array}$ & $\begin{array}{c}\text { T Statistik } \\
(\text { O/STDEV) }\end{array}$ & P Values \\
\hline $\begin{array}{l}\text { Kontrol Diri -> } \\
\text { Kedisiplinan }\end{array}$ & 0.284 & 0.278 & 0.123 & 2.309 & 0.021 \\
\hline $\begin{array}{l}\text { Dukungan Sosial Orang } \\
\text { Tua -> Kedisiplinan }\end{array}$ & 0.268 & 0.273 & 0.128 & 2.094 & 0.037 \\
\hline $\begin{array}{l}\text { Motivasi Belajar -> } \\
\text { Kedisiplinan }\end{array}$ & 0.508 & 0.508 & 0.150 & 3.376 & 0.001 \\
\hline $\begin{array}{l}\text { Kontrol Diri -> Motivasi } \\
\text { Belajar -> Kedisiplinan }\end{array}$ & 0.197 & 0.196 & 0.080 & 2.467 & 0.014 \\
\hline $\begin{array}{l}\text { Dukungan Sosial Orang } \\
\text { tua -> Motivasi Belajar -> } \\
\text { Kedisiplinan }\end{array}$ & 0.246 & 0.241 & 0.081 & 3.029 & 0.003 \\
\hline
\end{tabular}

Sumber: Data Primer diolah, 2021

Dari tabel diatas dapat dilihat bahwa kontrol diri mempunyai pengaruh positif yang signifikan $(\mathrm{O}=0.284)$ dengan kedisiplinan. Nilai $\mathrm{t}$ - statistik pada hubungan konstruk ini adalah $2.309>1.96$, dan nilai p - value $0.021<0.05$. Oleh karena itu, hipotesis pertama yang menyatakan ada pengaruh kontrol diri terhadap kedisiplinan pada siswa SMK. terbukti. 
Dari tabel diatas dapat dilihat bahwa dukungan sosial orang tua mempunyai pengaruh positif yang signifikan $(O=0.268)$ dengan kedisiplinan. Nilai $t$ - statistik pada hubungan konstruk ini adalah $2.094>1.96$, dan nilai $\mathrm{p}$ - value $0.037<0.05$. Oleh karena itu, hipotesis kedua yang menyatakan ada pengaruh dukungan sosial orang tua terhadap kedisiplinan pada siswa SMK terbukti.

Dari tabel diatas dapat dilihat bahwa motivasi belajar mempunyai pengaruh positif yang signifikan $(O=0.508)$ dengan kedisiplinan. nilai $\mathrm{t}$ - statistik adalah $3.376>1.96$, dan nilai $\mathrm{p}$ - value $0.001<0.05$. Oleh karena itu, hipotesis ketiga yang menyatakan ada pengaruh motivasi belajar terhadap kedisiplinan siswa SMK terbukti.

Dari tabel diatas dapat dilihat dapat dilihat pada tabel specific indirect effects. Dapat dilihat dari tabel tersebut bahwa hubungan kontrol diri terhadap kedisplinan yang dimediasi oleh motivasi bahwa motivasi belajarbisa memediasi hubungan antara kontrol diri terhadap kedisiplinan signifikan dengan nilai t - statistik $2.467>1.96$, dan nilai p value $0.014<0.05$ hal ini berarti motivasi berperan sebagai partial control. Partial control berarti bahwa dalam hubungan antar variabel terdapat hubungan langsung dan tidak langsung (Garson, 2016).

Dari tabel diatas dapat dilihat bahwa motivasi belajar bisa memediasi hubungan antara dukungan sosial orang tua terhadap kedisiplinan dapat dilihat pada tabel specific indirect effects. Dapat dilihat dari tabel tersebut bahwa hubungan dukungan sosial terhadap kedisplinan yang dimediasi oleh motivasi signifikan dengan nilai $\mathrm{t}$ - statistik $3.029>1.96$, dan nilai $\mathrm{p}$ - value $0.003<0.05$ hal ini berarti motivasi berperan sebagai partial control. Partial control berarti bahwa dalam hubungan antar variabel terdapat hubungan langsung dan tidak langsung (Garson, 2016).

\section{Diskusi}

\section{Ada pengaruh kontrol diri terhadap kedisiplinan pada siswa SMK}

Hasil penelitian hipotesis pertama menunjukkan ada pengaruh kontrol diri terhadap kedisiplinan pada siswa SMK. Hal ini sejalan dengan pendapat Sukmanasa (2016) menyatakan bahwa individu dengan tingkat kontrol diri yang tinggi lebih cenderung melakukan lebih baik di sekolah. Siswa yang menerapkan metode kontrol diri memungkinkan siswa untuk lebih baik dalam mengikuti kegiatan dan memahami pembelajaran di kelas. Hal ini menunjukkan bahwa siswa yang mampu mengontrol diri dengan baik akan menunjukkan sikap disiplin selama kegiatan pembelajaran. Disiplin akan membentuk perilaku dan membantu siswa untuk mengontrol diri. Siswa yang 
disiplin dalam belajar, akan mampu mengendalikan diri untuk melaksanakan tugas belajarnya dengan teratur.

Sejalan dengan penelitian Hadianti (2008) yang menyatakan bahwa kontrol diri mempengaruhi disiplin dengan mengatasi rasa malas dan rasa enggan dalam belajar, sehingga memungkinkan siswa untuk mencapai hasil belajar yang memuaskan. Disiplin belajar akan mengasah keterampilan dan daya ingat siswa, sebab mereka belajar menurut kesadaran diri. Penjelasan di atas juga sesuai dengan apa yang diutarakan Durkheim (dalam Gunawan , 2017: 110), mengemukakan bahwa terdapat dua unsur semangat disiplin, yaitu keinginan adanya keteraturan diri dan keinginan adanya pengendalian diri. Aspek pengendalian diri (self control) memiliki kontribusi dalam menciptakan perilaku disiplin, yaitu adanya ketaatan atau kepatuhan terhadap aturan, norma yang timbul/terjadi karena adanya dorongan dari dalam dirinya sendiri. Sementara individu yang kurang dalam pengendalian dirinya, cenderung untuk bertingkah laku negatif.

\section{Ada pengaruh dukungan sosial orang tua terhadap kedisiplinan pada siswa SMK.}

Hasil penelitian hipotesis kedua menunjukkan ada pengaruh kontrol diri terhadap kedisiplinan pada siswa SMK menyatakan ada pengaruh dukungan sosial orang tua terhadap kedisiplinan pada siswa SMK. Hal ini sejalan dengan pendapat Unaradjan (dalam Yuliantika, 2017: 37) menyatakan bahwa faktor timbulnya sikap disiplin salah satunya ada pada faktor eksternal yaitu keadaan keluarga yang merupakan tempat pertama dan utama pembinaan pribadi. Keluarga dapat menjadi faktor pendukung atau penghambat usaha pembinaan. Hal ini tergantung dari keadaan keluarga tersebut. Orangtua merupakan orang yang pertama dan utama yang bertanggung jawab terhadap kelangsungan hidup dan pendidikan anaknya. Sebagai orangtua harus dapat membantu dan mendukung terhadap segala usaha yang dilakukan oleh anaknya serta dapat memberikan pendidikan informal guna membantu pertumbuhan dan perkembangan anak tersebut serta untuk mengikuti atau melanjutkan pendidikan formal di sekolah. Peserta didik yang mendapatkan dukungan sosial dari orangtua akan mendapatkan suatu bantuan baik secara langsung, berupa penjelasan mengenai berperilaku yang baik di dalam sekolahan atau secara tidak langsung, sehingga setiap perbuatan yang dilakukan peserta didik dapat dipertanggungjwabkan dan peserta didik dapat menjadi pribadi yang disiplin.

Hasil penelitian ini sejalan dengan hasil penelitian yang dilakukan oleh Hidayat (2013) tentang peningkatan kerjasama antara guru dengan dukungan sosial orang tua untuk perserta didik yang dibangun melalui komunikasi formal dan non-formal dapat meningkatkan berperilaku disiplin peserta didik dalam mengikuti proses belajar mengajar 
di sekolah. Hal ini dapat dikatakan bahwa semakin baik tingkat kerjasama dukungan sosial orang tua dengan guru di sekolah maka akan berdampak pada semakin meningkatnya disiplin peserta didik dalam mengikuti proses belajar mengajar di sekolah, dan sebaliknya jika kerjasama orang tua dengan guru kurang erat maka akan berdampak pada semakin rendahnya disiplin peserta didik.

\section{Ada pengaruh motivasi belajar terhadap kedisiplinan pada siswa SMK}

Hasil penelitian hipotesis ketiga menunjukkan ada pengaruh motivasi belajar terhadap kedisiplinan pada siswa SMK. Motivasi belajar adalah daya penggerak atau pendorong yang ada di dalam diri individu untuk melakukan sesuatu demi mencapai suatu tujuan (Khalsa, 2007). Adanya dorongan dan kekuatan dalam diri seseorang, maka diharapkan pula dapat mempengaruhi disiplin siswa dalam belajar. Sehingga dapat meningkatkan keberhasilan dalam belajar siswa dan juga siswa semakin rajin, kreatif, dan aktif dalam belajarnya. Motivasi menentukan tingkat berhasil atau gagalnya kegiatan belajar siswa, pembelajaran yang bermotivasi pada hakikatnya adalah pembelajaran yang sesuai dengan kebutuhan dan minat, yang ada pada diri siswa. Motivasi diperlukan untuk menumbuhkan sikap disiplin siswa. Peserta didik harus di motivasi agar mencapai disiplin yang tinggi sehingga menjadi sumber daya yang berkualitas.

Sejalan dengan penelitian Tu'u (2004) bahwa pemberian motivasi belajar pada siswa disaat pemberian layanan pembelajaran yang baik tidaklah mudah, banyak faktor yang mempengaruhi antara lain pendidik, orang tua, dan siswa. Disiplin memberi dampak suatu kondisi yang tercipta dan terbentuk dari serangkaian perilaku yang menunjukkan nilai ketaatan, kepatuhan, kesetiaan atau keterikatan terhadap suatu peraturan tata tertib.

\section{Ada pengaruh kontrol diri terhadap kedisiplinan melalui motivasi belajar pada} siswa SMK.

Hasil penelitian hipotesis keempat menunjukan ada pengaruh positif kontrol diri terhadap kedisplinan melalui motivasi belajar. Sikap kontrol diri yang di mediasi oleh motivasi belajar yang tinggi penting dimiliki oleh setiap siswa karena dengan kontrol diri yang di mediasi oleh motivasi belajar yang tinggi akan memudahkan siswa dalam kedisiplinan secara terarah dan teratur. Siswa yang menyadari bahwa belajar tanpa adanya suatu paksaan, siswa menunjukkan kontrol diri yang memiliki kecenderungan motivasi yang tinggi dalam dirinya disamping itu juga akan timbul suatu kedisiplinan dalam diri siswa. Mereka menyadari bahwa dengan kontrol diri dan juga adanya motivasi belajar dalam dirinya akan mempermudah kelancaran di dalam proses pendidikan. Rasa segan, malas, dan membolos akan teratasi dengan disiplin. Siswa memerlukan disiplin 
belajar sehingga dapat mengkondisikan diri untuk belajar sesuai dengan harapan-harapan yang terbentuk dari masyarakat.

Sejalan dengan penelitian Amri (2013) bahwa disiplin berkaitan erat dengan proses pelatihan yang dilakukan oleh pihak yang memberi pengarahan dan bimbingan dalam kegiatan pengajaran. Seorang siswa perlu memiliki sikap kontrol diri yang di mediasi oleh motivasi belajar dengan melakukan latihan yang memperkuat dirinya sendiri untuk selalu terbiasa patuh dan meningkatkan kedisiplinan diri.

\section{Ada pengaruh dukungan sosial orang tua terhadap kedisiplinan melalui motivasi belajar pada siswa SMK.}

Hasil penelitian hipotesis kelima menunjukan ada pengaruh positif dukungan sosial orang tua terhadap kedisiplinan melalui motivasi belajar pada siswa SMK. Salah satu faktor yang mempengaruhi kedisiplinan siswa yaitu dukungan sosial melalui motivasi belajar. Individu yang memiliki motivasi berprestasi tinggi akan berjuang dan berusaha keras untuk meraih sukses. Motivasi belajar sangat dibutuhkan oleh siswa. Motivasi belajar yang tinggi mendorong siswa untuk mengatasi rintangan belajar dan tidak putus asa saat menjumpai kesulitan dalam mengerjakan tugas. Siswa yang memiliki dukungan sosial melalui motivasi belajar yang tinggi akan melakukan berbagai usaha dan berjuang keras untuk mendapatkan nilai terbaik. Motivasi belajar tinggi yang dimiliki siswa diharapkan dapat mendorong siswa untuk mencapai kedisiplinan yang maksimal. Motivasi belajar dapat tumbuh karena dorongan dari luar diri siswa yang diberikan oleh dukungan sosial orang tua. Orang tua berperan penting dalam membantu anak menumbuhkan motivasi berprestasi yang tinggi. Orang tua adalah guru pertama bagi anak karena yang pertama kali mendidik dan menanamkan pendidikan kepada anak adalah orang tua. Orang tua memiliki potensi dalam membantu pendidikan anak secara lebih efektif. Dorongan sosial orang tua sangat penting dalam mengarahkan tujuan belajar anak. Sejalan dengan penelitian Anoraga (2014) bahwa dukungan sosial yang diberikan orang tua akan mendorong anak termotivasi dengan baik dan berusaha untuk meraih kedisiplinanyang tinggi. Jika orang tua memberikan dukungan sosial pada anak, maka akan tumbuh motivasi berprestasi dalam diri anak dan berlanjut pada hasil akhir yaitu kedisiplinan.

Penelitan ini tidak terlepas dari beberapa kelemahan yang ada diantaranya yaitu, berkaitan dengan pengisian skala penelitian. saat pelaksanaan penelitian, peneliti tidak dapat mengawasi secara langsung proses pengisian skala dikarenakan proses pengambilan data menggunakan google form, kemungkinan subjek dalam mengisi skala 
penelitian sekedarnya saja, adanya social desirability dimana subjek mengikuti jawaban responden lainnya, dan kemungkinan subjek tidak jujur saat mengisi skala.

\section{Simpulan}

Berdasarkan hasil penelitian yang telah dilakukan, maka kesimpulan yang dapat diambil dari penelitian ini adalah terdapat pengaruh posotif kontrol diri terhadap kedisiplinan, terdapat pengaruh positif dukungan sosial orang tua terhadap kedisiplinan, terdapat pengaruh positif motivasi belajar terhadap kedisiplinan, terdapat pengaruh positif antara kontrol diri terhadap kedisiplinan melalui motivasi belajar dan terdapat pengaruh positif dukungan sosial orang tua terhadap kedisiplinan melalui motivasi belajar.

\section{Saran}

Hasil penelitian ini nantinya diharapkan dapat memberikan manfaat kepada pihak-pihak terkait, antara lain : bagi guru disarankan membantu siswa untuk mengembangkan kemampuan kontrol diri dengam memberikan layanan dan bimbingan kelompok maupun konseling individual dan memperbaiki perilaku disiplin siswa dalam mematuhi tata tertib sekolah serta meningkatkan dan mempertahankan motivasi belajar agar disiplin belajar siswa dapat tertanam. Bagi Siswa disarankan akan dapat meningkatkan kedisiplinan dan kontrol diri agar tidak melakukan pelanggaran peraturan baik di lingkungkan sekolah maupun di luar lingkungan sekolah serta siswa semakin semangat dalam meningakatkan dan mempertahankan motivasi belajar dalam menyelesaikan tugas-tugas. Bagi orang tua disarankan tetap memberikan dukungan baik dukungan verbal maupun non verbal karena dukungan yang diberikan akan memotivasi anak dalam kegitan belajarnya dan dukungan tersebut dapat membantu anak berperilaku baik, taat dan patuh akan aturan yang ditetapkan dan memliki rasa tanggung jawab atas tindakannya. Bagi peneliti selanjutnya diharapkan dapat menambah variabel lain selain kontrol diri, dukungan sosial orang tua, karena masih banyak faktor yang mempengaruhi kedisiplinan dan juga menambahkan variabel intervening selain motivasi belajar. Peneliti selanjutnya diharapkan memperhatian keterbatasan penelitian yang ada dengan memberikan pengawasan saat melakukan pengambilan data penelitian.

\section{Daftar pustaka}

Al Baqi,S., Abdul, L.A \& Tyas, S.L. (2017). Faktor Pendudukung Motivasi Berperilaku Disiplin Pada Santri Pondok Pesantren. Jurnal Educan, Vol. 1, No. 01, Februari 2017. 
Amri, Sofan. (2013). Pengembangan dan Model Pembelajaran dalam Kurikulum 2013. Jakarta: Prestasi Pustaka

Anoraga, P. (2014). Psikologi Kerja. Jakarta: Rineka Cipta.

Elly, R. (2016). Hubungan Kedisiplinan terhadap Hasil Belajar Siswa Kelas V di SD Negeri 10 Banda Aceh: Jurnal Pesona Dasar. 3 (4), 6-23.

Garson, G. D. (2016) Partial Least Squares: Regression \& Structural Equation Models, Statistical Associates Publishing. Asheboro, NC: Statistical Associates Publishing.

Gunawan, L.N.(2017). Hubungan Antara Kontrol Diri Dan Penyesuaian Diri Dengan Kedisiplinan Siswa Mts Sulaiman Yasin Samarinda. Psikoborneo, Volume 5, Nomor 1, $2017: 104-117$.

Hadianti, L. S. (2008). Pengaruh Pelaksanaan Tata Tertib Sekolah Terhadap Kedisiplinan Belajar Siswa (Penelitian Deskriptif Analisis di SDN Sukakarya II Kecamatan Samarang Kabupaten Garut. Jurnal Pendidikan, 2 (1), 1-8.

Hidayat, H. Syarif. (2013). Pengaruh Kerjasama Orangtua dan Guru terhadap Disiplin Peserta Didik di Sekolah Menengah Pertama (SMP) Negeri Kecamatan Jagakarsa Jakarta Selatan. Jurnal Ilmiah WIDYA. Vol. 01, No. 02, hlm. 92 - 99.

Indriani, S. (2013). The Implementation Of Reality Group Counseling To Omprove Dicipline Behaviour Student Class VIII-G In State Junior High School 28 Surabaya. Journal mahasiswa bimbingan dan konseling, Vol. 01, No. 01.

Masruroh, Ratna Ngaini. (2019). Pengaruh Kontrol Diri Dan Pengelolaan Kelas Terhadap Disiplin Belajar Siswa Kelas IV SD Se-Kecamatan Sentolo Kabupaten Kulon Progo. Jurnal Pendidikan Guru Sekolah Dasar. Edisi 9 Tahun Ke-8.

Ningsih, R. (2015). Hubungan Persepsi Siswa Terhadap Kedisiplinan Dan Self Control Dengan Tingkat Kedidiplinan Di Smk Karya Rini Yogyakarta. Jurnal Bimbingan Dan Konseling. Edisi 6. Vol. 4, 1-12.

. (2018). Pengaruh Kontrol Diri terhadap Perilaku Disiplin Remaja: Jurnal Psikoedukasi dan Konseling. 2 (2), 56-61.

Sani, Mar'ati K. (2019). Hubungan Pemberian Dukungan Sosial Orang Tua Dengan Disiplin Belajar Siswa SD Kelas IV. Jurnal Pendidikan Guru Sekolah Dasar. Edisi 4 Tahun ke 8 2019.

Santrock, John W. (2012). Life span development (Terjemahan). Jakarta: Erlangga.

Sugiarto, Tri, dan Padmi. (2019). Faktor Kedisiplinan Belajar Pada Siswa Kelas X SMK Larenda Brebes. Jurnal Mimbar Ilmu, Vol. 24 No. 2, 2019.

Sukmanasa, E. (2016). Hubungan Antaara Disiplin Belajar dengan Hasil Belajar Pada Mata Pelajaran Ilmu Pengetahuan Sosial. Jurnal Kreatif. Jurnal Kependidikan Dasar, 7 (1), 11-24. 
Philanthropy Journal of Psychology

Vol 5 Nomor 1 (2021), 92-108

ISSN 2580-6076 (Print), ISSN 2580-8532 (Online)

Tu’u, T. (2008). Peran disiplin pada perilaku dan prestasi siswa. Jakarta: Grasindo

Uno, Hamzah B. 2012. Teori Motivasi dan Pengukurannya: Analisis di Bidang Pendidikan. Jakarta: Bumi Aksara.

Wicaksono, D. Ary. (2014). Kedisiplinan Siswa Ditinjau dari Dukungan Sosial dan Pola Asuh Otoriter Orangtua pada Siswa yang Berlatar Belakang Berbeda (TNI dan NonTNI). Jurnal Widya Warta. No. 01, ISSN 0854- 1981.

Yuliyantika.,S. (2017).Analisis Faktor-Faktor yang Mempengaruhi Disiplin Belajar Siswa SMA Bhakti Yasa Singaraja Tahun Ajaran 2016/2017. Journal JurusanPendidikan Ekonomi Undiksha.Vol.9 (1) 3. 